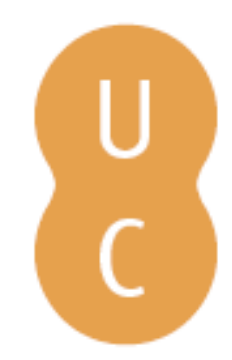

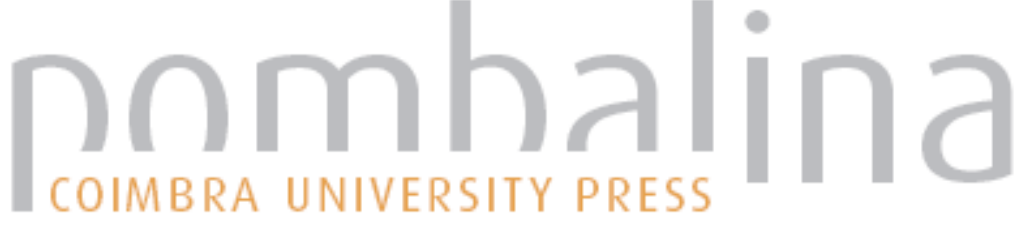

\section{Geoarqueologia na bacia do rio Peruaçu (Estado de Minas Gerais, Brasil)}

Autor(es): $\quad$ Rodet, M. J.

Publicado por: Imprensa da Universidade de Coimbra

URL

persistente: URI:http://hdl.handle.net/10316.2/31447

DOI: $\quad$ DOI:http://dx.doi.org/10.14195/978-989-26-0531-9_20

Accessed : $\quad$ 26-Apr-2023 14:47:08

A navegação consulta e descarregamento dos títulos inseridos nas Bibliotecas Digitais UC Digitalis, UC Pombalina e UC Impactum, pressupõem a aceitação plena e sem reservas dos Termos e Condições de Uso destas Bibliotecas Digitais, disponíveis em https://digitalis.uc.pt/pt-pt/termos.

Conforme exposto nos referidos Termos e Condições de Uso, o descarregamento de títulos de acesso restrito requer uma licença válida de autorização devendo o utilizador aceder ao(s) documento(s) a partir de um endereço de IP da instituição detentora da supramencionada licença.

Ao utilizador é apenas permitido o descarregamento para uso pessoal, pelo que o emprego do(s) título(s) descarregado(s) para outro fim, designadamente comercial, carece de autorização do respetivo autor ou editor da obra.

Na medida em que todas as obras da UC Digitalis se encontram protegidas pelo Código do Direito de Autor e Direitos Conexos e demais legislação aplicável, toda a cópia, parcial ou total, deste documento, nos casos em que é legalmente admitida, deverá conter ou fazer-se acompanhar por este aviso.

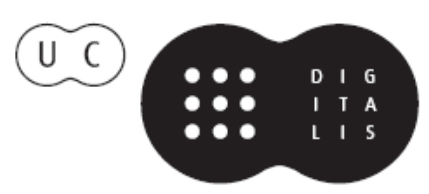





\title{
GEOARQUEOLOGIA NA BACIA DO RIO PERUAÇU (ESTADO DE MINAS GERAIS, BRASIL)
}

\author{
GEOARCHEOLOGY IN THE PERUAÇU RIVER BASIN \\ (MINAS GERAIS STATE, BRAZIL)
}

M. J. Rodet $^{1}$

\begin{abstract}
Resumo - A paisagem condiciona a ocupação humana e, em consequência, condiciona a abordagem do arqueólogo. Sendo algo dinâmico, a evolução da paisagem tem conseqüências sobre os grupos humanos pré-históricos (e atuais). Neste sentido, pode-se pensar em três dimensóes básicas para a pré-história: os recursos alimentares, as jazidas de matérias-primas líticas e a dimensão do imaginário, esta última percebida a partir da apropriação do espaço físico. Pode-se afirmar que, na pré-história, os grupos humanos dependem e agem sobre o seu meio natural. Neste sentido, eles se apropriam do espaço físico no qual buscam atender as suas necessidades, e é claro que a qualidade dos recursos guia estas culturas que investem neste espaço em funçáo de suas necessidades e dos recursos que eles oferecem (RODET et al. 2008).

Palavras-chave - paisagem; jazida lítica; pré-história; Brasil

Abstract - The landscape guides the human occupation and therefore, guides the archaeologist's approach. Due to being something dynamic, the landscape evolution has influenced the pre-historic (and the present) human groups. In this way, one can think about three different basic dimensions for the prehistoric period: the food resources, the deposits of raw materials and the imaginary dimension, the last one seen from the appropriation of the physical space. One can assert that at the prehistoric time the human groups depend and act over their natural environment. So, they appropriate the physical space over which they look forward to fill in their needs and, it is clear that the resource's quality guide these cultures, that invest in this space according to their needs and resources they offer (RODET et al. 2008).
\end{abstract}

Keywords - landscape; deposits of raw materials; pre-history; Brazil

\footnotetext{
${ }^{1}$ Departamento de Antropologia e Arqueologia, Faculdade de Filosofia e Ciencias Humanas, Universidade Federal de Minas Gerais, Belo Horizonte, Brasil; jacqueline.rodet@gmail.com.
} 


\section{1 - Introdução}

As pesquisas geoarqueologicas realizadas na bacia do rio Peruaçu, norte do estado de Minas Gerais, demonstraram a apropriação do espaço pelos grupos humanos pré-históricos (Fig. 1). Dentro de uma perspectiva que engloba pelo menos três escalas espaciais - o sítio arqueológico, o compartimento e a bacia -, a abordagem arqueológica da bacia do rio Peruaçu demonstrou claramente a apropriação e a transformação destes espaços pelos grupos pré-históricos (RODET, 2006). O estudo geomorfológico permitiu a divisão espacial da bacia, onde certos compartimentos ofereceram qualidades específicas, principalmente relacionados ao substrato rochoso, às qualidades das jazidas líticas, as quais estão presentes em certos compartimentos e ausentes em outros. O estudo geoarqueológico revelou a utilização de rochas e minerais como suportes das indústrias líticas pré-históricas, provenientes de alguns dos compartimentos ou, às vezes, de fora da bacia. Por outro lado, a apreensão por parte dos grupos pré-históricos do espaço dos abrigos calcários pôde ser claramente notado ao longo das ocupaçôes. O alto vale foi, muito provavelmente, local de caça organizada. Estas constataçôes demonstram uma apropriação da paisagem e sua utilização diferenciada, tanto espacial quanto temporal, segundo as necessidades dos grupos (RODET, 2006; RODET et al., 2008).

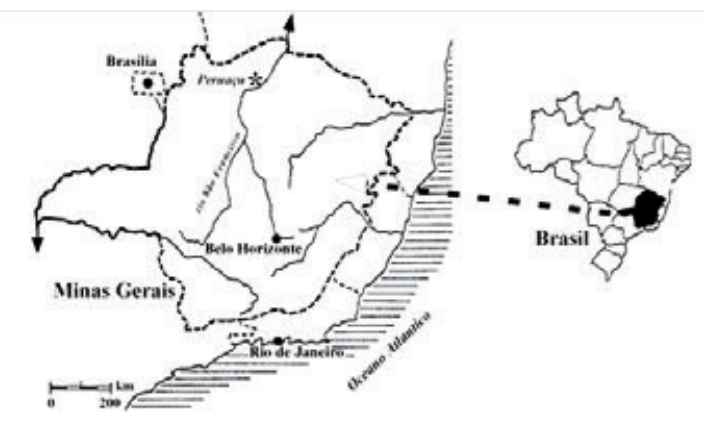

Fig. 1 - Localização da bacia do rio Peruaçu (modificado RODET et al., 2002).

Tributária da margem esquerda do grande rio São Francisco, a bacia do rio Peruaçu de $195 \mathrm{~km}^{2}$ (PILÓ, 1997) percorre, de oeste a leste, quatro grandes unidades geomorfológicas que se sucedem, de montante à jusante (Fig. 2): o compartimento do alto vale, setor das nascentes, situada dentro da formação dos arenitos Urucuia; a zona de transição (entre o alto vale e compartimento do cânion) onde se sucedem a formação Urucuia, os calcários do Grupo Bambuí e os elementos do embasamento granítico; o compartimento do cânion onde o rio realiza a travessia do platô calcário e, finalmente, a zona da planície aluvial ou depressão sanfranciscana onde se realiza a confluência do rio Peruaçu e o rio São Francisco (RODET et al., 2003; RODET, 2006; entre outros).

\section{2 - Procedimentos metodológicos}

Serão a geomorfologia e a arqueologia a base desta abordagem metodológica. A primeira oferece uma análise minuciosa do sistema morfodinâmico definido 
(RODET \& RODET, 1999 ; RODET et al., 2002; RODET, 2006; RODET et al., 2008), qual seja:

- a definição do sistema da bacia do rio Peruaçu: seus limites, dimensóes, geometrias, além de sua dinâmica climática, funcionamento hidrológico, evolução geomorfológica, etc.

- $\quad$ ainda, a compartimentação do sistema: realizado a partir da identificação de sub-sistemas (nascentes, confluências importantes, maciços carbonáticos, embasamento).

- e, finalmente, a realização de uma tipologia de jazidas de matérias-primas líticas disponíveis, as quais resultam da evolução geomorfológica do setor, que se tornou "armadilhas" para as matérias-primas líticas (silexitos presos nos macicos calcários, "ilhas" de seixos, velhos terraços). Esses locais foram certamente conhecidos e utilizados pelos grupos pré-históricos (RODET \& RODET, 2001; RODET, 2006; M.J. RODET et al., 2008).

Assim, é importante notar que o estudo da evolução geomorfológica permite primeiro definir a repartição espacial das jazidas potencias de matéria-prima lítica e, em seguida, criar um modelo de prospecção que controla em campo não só a presença das jazidas, mas também as diferentes utilizaçóes que os grupos pré-históricos davam aos variados espaços que a paisagem oferecia.

Em seguida, o esforço foi o de compreender a relação entre grupos humanos e meio físico, isto é, como os pré-históricos teriam aproveitado os conteúdos específicos dos diferentes elementos geomorfológicos (resultantes da evolução), particularmente das jazidas líticas, para produzir suas indústrias líticas. Neste sentido, os sítios arqueológicos tornam-se marcadores territoriais.

Teriam eles ocupado de maneira homogênea a bacia do rio Peruaçu ou teriam ocupado os compartimentos de maneira diferenciada ou complementar? Estariam estes grupos ligados principalmente ao rio Peruaçu ou dependeriam de um rio maior, tal qual o São Francisco?

A partir das prospecçōes, da utilização de GPS (Global Positioning System) para situar os sítios no espaço, da compreensao do quadro geomorfológico e seus funcionamentos (os obstáculos naturais e as possibilidades de passagem entre os setores, como os córregos, os vales, etc.), pretendeu-se buscar entender como os grupos se adaptaram às condições destes diferentes meios. Neste sentido, utilizamos a noção de território, que pode ser dividido em vários espaços de vida: atividade doméstica, aquisição de matérias minerais, caça, setor de passagem, etc. O conjunto espacial percorrido toma valor de "sistema antrópico" (RODET et al., 2008).

\section{3 - A compartimentação da bacia rio Peruacu}

Assim, a partir da análise geomorfológica, num primeiro momento a bacia de estudo foi abordada como um sistema, ou seja, como um conjunto de elementos que constituem uma unidade, a qual chamamos aqui de "a bacia" (RODET \& RODET, 2001; RODET, 2006). Em seguida, o sistema foi dividido em subsistemas. Esta divisão foi baseada sobre as qualidades específicas de cada setor (geológicas, geomorfológicas e biológicas) Cada um 
destes elementos tem um valor e uma função por ele mesmo, mas também em relação ao conjunto. Para a bacia do rio Peruaçu foram distinguidos 4 sub-sistemas: o alto vale, a zona de transição, o compartimento do carste e o compartimento da planície aluvial (Fig. 2).

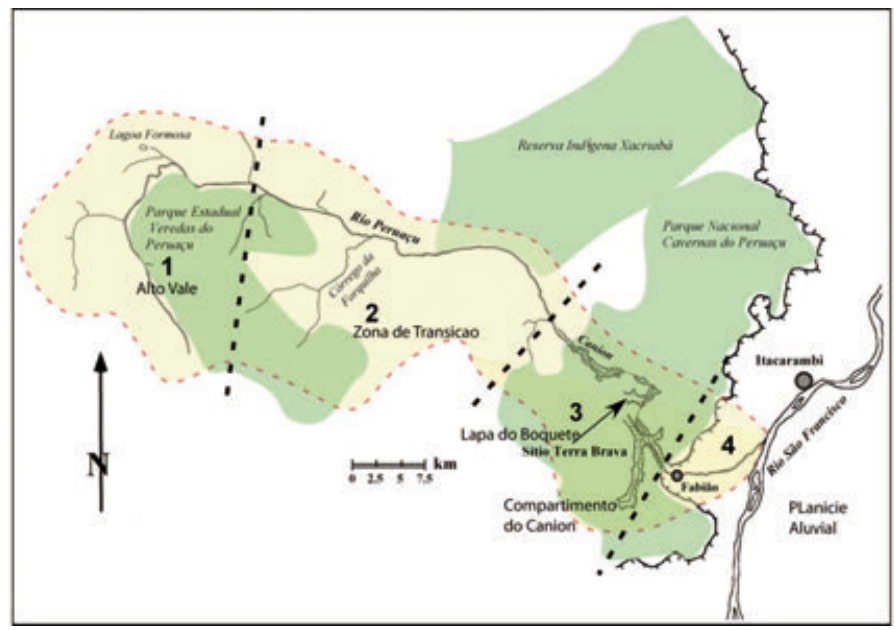

Fig. 2 - Compartimentação da bacia: 1. Alto Vale, 2. Zona de Transição, 3. Compartimento do Cânion, 4. Compartimento da Planície Aluvial (modificado RODET, 2006).

Cada um destes compartimentos contribui com elementos para o funcionamento do conjunto/sistema, mas também cada um deles tendo suas especificidades. O rio, quando passa dentro de cada compartimento deposita e/ou toma elementos para transportá-los ou depositá-los mais longe, sejam líquidos ou sólidos (RODET et al., 2005; RODET, 2006). Exemplo, a matéria-prima lítica, a qual é arrancada dos primeiros compartimentos, é trazida para dentro do leito do rio, onde é transportada e, em seguida, em forma de seixo (grandes, médios ou pequenos), será depositada em certos compartimentos mais abaixo. Assim, o arqueólogo trata cada um desses compartimentos de maneira diferenciada, pois eles têm paisagens e recursos muito distintos:

- O alto vale se desenvolve de 750 a $830 \mathrm{~m}$ de altitude, apresenta o bioma do tipo cerrado (lato sensu), misturado a zonas úmidas de veredas compostas principalmente pela palmeira Buriti (Mauritia vinifera), com grande diversidade de flora e fauna. Certamente o setor serviu de fonte de matéria-prima aos grupos passados, tanto em plantas medicinais e comestíveis, quanto em caça e plumária. No entanto, não existem maciços rochosos expostos, somente o arenito completamente alterado em areias.

- A zona de transição, está situada entre as cotas 657 e $750 \mathrm{~m}$, e faz a ligação entre a regiấo das nascentes, o alto vale, e o compartimento do cânion. A vegetaçáo, assim como seu substrato rochoso, oferece um mosaico entre o Cerrado e a Caatinga, e também apresenta florestas-galeria nas margens do rio, em muito composta por palmeiras Buritis. Além destas, nas proximidades do maciço calcário, nota-se a presença de bromélias e de gameleiras (Fícus insípida). Os recursos animais náo diferem daqueles presentes no alto vale (tamanduás, antas, porcos selvagens, lobos, onças etc.). 
O rio é aqui, em função do desnível que começa a aparecer e do carste, mais rápido e mais profundo, e as dinâmicas da água e do relevo permitem que as matérias-primas líticas sejam arrancadas dos maciços e transportadas. A partir deste setor, o rio Peruaçu apresenta várias jazidas de matéria-prima de qualidades diferenciadas, as quais foram efetivamente (ou potencialmente) utilizadas pelos grupos passados.

A riqueza litológica do compartimento certamente influenciou sua ocupação durante a pré-história. Certos tipos de silexitos e de minerais do tipo quartzo e jaspe só foram observados (até o momento) neste setor. Os blocos de arenito rosado, o aparecimento dos primeiros calcários, além da presença de uma janela geológica (que fez surgir em superfície o substrato granítico), demonstram a complexidade geológica do setor. Todos estes materiais foram utilizados como suportes nas indústrias líticas pré-históricas, presentes nos sítios arqueológicos do compartimento do cânion. A proximidade com o cânion, a riqueza de suas jazidas líticas, (ou ainda sua capacidade de conservar os elementos arqueológicos), revela este compartimento rico em vestígios pré-históricos e foi a partir daqui que os sítios arqueológicos foram observados.

- O compartimento do cânion se caracteriza por seu imponente relevo cárstico (650 - 500m), 17 km de canion (abrigos sob rocha, grutas, grande cânion, dolinas, ravinas, etc.) e por sua importante ocupação humana - aproximadamente 100 sítios arqueológicos foram catalogados, em grande parte, uma ocupação constante desde a passagem Pleistoceno/Holoceno até o século XVIII, momento da chegada dos neobrasileiros (bandeirantes paulistas). Neste momento, as populaçôes são dizimadas. A vegetação dos afloramentos calcários é do tipo floresta decídua (Caatinga) e abriga uma fauna específica, mas também recebe os animais de outros biomas, pois serve de caminho entre o alto vale e a planície aluvial. No que se refere à freqüentação humana, a mesma parece estar diretamente relacionada ao carste: abrigos, entradas de gruta, áreas de poljes (mais abertas dentro do carste) foram sistematicamente utilizados.

Sobre os maciços calcários nota-se a presença de uma cobertura de siltito (Nhandituba) e de arenito (Urucuia), muitas vezes sob a forma de relíquias (sítio arqueológico do Judas), esta às vezes aprisionada dentro do carste. As matérias-primas líticas disponíveis neste compartimento são muito diversificadas: o calcário, os blocos de silexito presentes nos velhos terraços do Peruaçu ou dentro dos paleo-preenchimentos litificados ou ainda dentro da antiga cobertura, além de grande variedade de seixos dentro do rio Peruaçu, e de blocos de arenito silicificado e de calcedonia. Outra matéria-prima característica deste setor são os nódulos de silexitos presentes dentro dos calcários ("bonecas de sílex", J.R. Chiavegatto, com. pessoal).

O essencial das escavaçóes e, em conseqüência, das indústrias líticas estudadas são provenientes deste setor, sendo este o melhor estudado até agora, em razão da facilidade de observação dos sítios de abrigo (pinturas rupestres até mais de $10 \mathrm{~m}$ de altura do solo atual), mas também pela abundância e do estado de conservação dos vestígios arqueológicos (corpos semi-mumificados, fibras, instrumentos em madeira, etc.). As escavaçóes concentraram-se dentro destes abrigos, onde as acumulaçóes estratigráficas permitiram estabelecer uma cronologia cultural das populaçóes que os freqüentaram (RODET, 2006; RODET et al., 2008). 
- A planície aluvial, está situada entre as cotas 500-440 m, quando o rio Peruaçu encontra o grande vale carstificado do São Francisco (Fig. 1), de aproximadamente $30 \mathrm{~km}$ de largura. O relevo apresenta uma topografia plana, permeada de dolinas e de muitas lagoas sazonais.

Há uma grande antropização do setor desde o século XVIII, quando os bandeirantes dizimam as populaçôes indígenas, derrubam as matas e instalam nas margens do rio São Francisco as grandes fazendas de gado e algodão. Há muitos relatos do grande número de aldeias que havia ao longo do rio São Francisco. Alguns desses locais foram encontrados e escavados.

Por volta de 1820, SPIX \& MARTIUS (1981) relatam que nas margens do rio São Francisco havia grandes zonas de brejo, grande zonas pantaneiras, alagadas, fazendo parte do leito maior de inundação. Neste setor havia misturado a vegetação, barro, madeira flutuante, emaranhado de espinhos, de carcassas de animais transportados pelas inundações, etc., formando um setor quase impenetrável, de odor insuportável. Esta zona estava cercada por uma floresta de grandes árvores e de lagoas ricas em peixes e aves.

Este compartimento se diferencia dos outros principalmente em função da possibilidade de navegaçáo. O rio São Francisco (Opara em lingua Tupiguarani, que significa a grande água), desemboca no mar e adentra o sertão atravessando 5 estados brasileiros sobre uma extensão de quase 3000 quilômetros. Por suas características ele foi utilizado como caminho de entrada e saída para os europeus e, muito antes, pelos grupos pré-históricos. Outra questão importante é a grande quantidade e variedade de peixes presentes em suas águas. Além dessas características, existe ainda as matérias-primas líticas que apresentam aí outras dimensôes e especificidades. Primeiro, as grandes cascalheiras presentes nas margens do rio São Francisco, mas também os grandes seixos de arenito silicificado, quartzito, quartzo, provenientes de outras bacias. E, finalmente, os abrigos nos morros calcários residuais da grande bacia sanfrascana.

\section{4 - A ocupação humana ao longo da bacia}

A paisagem condiciona a ocupação humana e, em consequência, condiciona a abordagem do arqueólogo. Sendo algo dinâmico, a evolução da paisagem tem implicações sobre os grupos humanos pré-históricos (e atuais). A percepção dos espaços que compóem a bacia do rio Peruaçu pelos grupos pré-históricos fez com que eles os utilizassem de maneira diferenciada. A intenção do arqueólogo é buscar uma classificação a partir dos elementos existentes em cada um dos compartimentos: como setores de caça ou pesca, navegação, jazidas de matérias-primas líticas, como lugar de acampamento prolongado ou temporário, como locais de passagem ou ainda como sítios à vocação cerimonial. O grupo socializa o espaço dentro do qual ele se estabelece (RODET, 2006) e o pesquisador busca as inter-relaçôes a partir dos vestígios deixados.

$\mathrm{Na}$ bacia do rio Peruaçu, no início das ocupaçôes humanas (12.000 BP) o abrigo é um lugar de passagem, que pouco a pouco toma uma outra dimensão, ou seja, sua vocação cerimonial (pinturas, sepulturas, oferendas, etc.). As freqüentações dos sítios abrigados mostram, através dos estudos inter e intra-sítios, uma diferenciação de suas 
utilizaçóes ao longo do tempo, evoluindo de simples acampamento de passagem para um espaço à vocação ritual (RODET, 2006):

- Durante a passagem Pleistoceno-Holoceno e logo no início do Holoceno (12000-10000 BP), os abrigos são utilizados de maneira discreta: há algumas fogueiras com poucos restos alimentícios (fragmentos de osso, nozes de palmeiras) e instrumentos líticos fragmentados pelo fogo. Estes últimos demonstram um aprovisionamento em matéria-prima baseado principalmente em um silexito de granulometria fina e homogênea, muito apto ao lascamento (menos freqüente são os arenitos de coloração rosada e acinzentada, além de uma indústria realizada sobre o calcário). Os suportes utilizados para a produção dos utensílios mais característicos desse período (unifaciais à seção plano-convexa e unifaciais achatados, ponta de projétil bifacial) são as lascas longas e pouco espessas transformadas por percussão macia (algumas vezes nota-se a presença de peças que tiveram um contato térmico antes do lascamento).

- Durante o Holoceno inicial (10000-8000 BP), parece haver uma modificação tecno-econômica significativa. Contrariamente aos níveis precedentes, a escolha pela matéria-prima não está mais calcada sobre a utilização de uma rocha homogênea e fina, mas oferece uma grande diversidade (menor exigência qualitativa), incluindo silexitos de grãos médios a grossos, pouco homogêneos (persiste a utilização discreta do calcário, do arenito e da calcedônia). Estas escolhas podem corresponder a uma modificação no comportamento tecnológico. As indústrias líticas mais elaboradas são ainda produzidas sobre suportes alongados, podendo utilizar grandes seixos trazidos do rio Peruaçu. No entanto, estes instrumentos, classificados como marcadores culturais, são cada vez mais raros; poucas peças foram encontradas, indicando uma possível perda no savoir-faire mais elaborado ao longo do período. Esses dados sugerem uma evolução das primeiras indústrias líticas que se transformam pouco a pouco até desaparecerem entre 9000 e 8000 BP (pelo menos nos setores escavados dos sítios arqueológicos).

No início do período, as fogueiras e os vestígios líticos são ainda representativos de uma passagem rápida. Os vestígios deixados nas fogueiras não variam muito do período anterior (lascas de reavivagem, poucos restos alimentares). As modificaçóes mais importantes na maneira de ocupar o espaço acontecem por volta de $9000 \mathrm{BP}$, quando são encontrados os primeiros sinais de uma representaçáo gráfica, incisóes realizadas sobre um bloco calcário. Em seguida, em torno de 8000 BP, outra modificação acontece: as fogueiras não têm somente restos alimentares, mas têm também manchas de pigmentos.

- As transformações nas ocupaçóes dos abrigos persistem durante o período denominado Holoceno médio (8100 BP a aproximadamente $4000 \mathrm{BP}$ ), por volta de $7900 \mathrm{BP}$ e $7154 \mathrm{BP}$, quando aparecem os primeiros sepultamentos. Estes, aliado à ausência de uma indústria pouco característica, ilustram uma modificação qualitativa da ocupaçáo dos abrigos. Junto às fogueiras, aparecem agora os pigmentos, os quais são também encontrados dentro das fossas sepulcrais.

- No período seguinte, Holoceno recente (entre 4000 BP e 700 BP), a vocação cerimonial ou simbólica destes abrigos parece estar plenamente estabelecida. O local continua sendo utilizado para sepultamentos, mas a partir do aparecimento das 
plantas domesticadas, por volta de $2000 \mathrm{BP}$, passa a ser utilizado como local de "enterramento", ou depósito de estruturas contendo vegetais. Estas estruturas, durante muito tempo entendidas como silos, apresentam a peculiaridade de ter grande parte dos alimentos parcialmente consumidos (fragmentos de mandioca ralados, milhos sem gráos) ou vazios (frutos, cabaças, etc.), ou ainda a natureza de certos objetos que não remetem à alimentação tais como plumas, pregos de ferro, contas, etc. Tais dados levam a pensar que tais estruturas foram destinadas a outra coisa e não a simples estocagem de alimentos. É possível tratar-se, dentro de um contexto cerimonial, de oferendas, onde o que importa não é o alimento, mas a idéia do mesmo (RODET, 2006; FREITAS \& RODET, 2010). No mais, estes abrigos apresentam sempre as paredes pintadas, o que leva a uma associação entre as pinturas rupestres e os pigmentos (a única datação direta das pinturas é por volta de $3000 \mathrm{BP}$ ).

- Enfim, a última ocupação do vale (vestígios em subsuperfície e em superfície) ilustra uma modificação radical: se até então os abrigos não apresentaram muitos utensílios líticos, estes se tornam mais numerosos e presentes não só nos abrigos, mas também nos sítios a céu aberto. O número de fogueiras aumenta, e os restos encontrados também se diversificam. Estes vestígios podem refletir o contato com o colonizador que, desestruturando o modo tradicional de vida destas populaçóes, expulsa os índios das margens do rio São Francisco, forçando-os a se esconderem em setores mais distantes, de difícil acesso, como os cânions. Em conseqüência, a função dos abrigos pode ter se modificado e, em conseqüência, sua frequentação.

\section{5 - Consideraçôes finais}

A Arqueologia é uma disciplina que depende muito ds geociências. No caso deste estudo, a aplicação de métodos e técnicas da geomorfologia e geografia foi fundamental para a compartimentaçáo da bacia do rio Peruaçu e uma melhor compreensão da apropriação e transformação do espaço pelos grupos pré-históricos.

Ao longo dos estudos realizados na bacia do rio Peruaçu a tentativa foi aplicar uma abordagem sistêmica, baseada nas características geológicas, geomorfológicas e biológicas, o que permitiu a definiçáo de quatro subsistemas específicos.

Conclui-se que, no alto vale, zona de cerrado, a região é arenosa e pantanosa - sendo que o setor pantanoso impede a aproximação das margens do rio. Neste compartimento não foram encontrados sítios arqueológicos. Este setor, em função da grande quantidade de animais aí presente, foi, muito provavelmente, dedicado à caça e à coleta de vegetais. No momento da florada, entre novembro e fevereiro, o setor oferece uma diversidade vegetal importante, que atrai uma grande variedade de herbívoros e seus predadores. O pequizeiro (Caryocar brasiliense) atrai os porcos selvagens, que sobem o vale para consumir este fruto. A revoada de cupins atrai os tamanduás, que fazem deles seu principal alimento. As capivaras, que ao longo do ano vivem em pequenos bandos, se encontram neste período em grandes grupos para se acasalarem. Todos estes animais são certamente seguidos por outros predadores, inclusive os grupos humanos.

De acordo com as observaçóes de campo, somente a partir da zona de transição se pôde observar as primeiras jazidas líticas utilizáveis (granito, arenito, quartzo, calcário, etc.). A vegetação aqui é diversificada, cerrado e caatinga se misturam em um mosaico. 
O rio pode ser aqui aproximado. O relevo, antes plano, mostra aqui as primeiras torres, se tornando pouco a pouco imponente. Neste setor, são observados os primeiros vestígios de ocupação humana pré-histórica, em sítios a céu aberto (lascas líticas, fragmentos cerâmicos, fogueiras). O compartimento do cânion é representado pelo maciço calcário, onde o rio Peruaçu escavou $17 \mathrm{~km}$ de seu percurso dentro de galerias e gargantas. Os desmoronamentos destas cavernas originaram um imponente relevo cárstico, muitas vezes com paredes de até $200 \mathrm{~m}$ de altura. O local foi intensamente ocupado pelos grupos passados (diferentemente do dias atuais, quando estes locais de difícil acesso são, no geral, preteridos). Os pés das falésias e as entradas das grutas foram amplamente utilizadas pelos grupos pré-históricos, que transformaram estes espaços não só através de pinturas, incisóes, picoteados, mas também a partir da utilização dos mesmos para enterrar os seus mortos ou fazer oferendas. No que se refere às manifestaçoes rupestres, ISNARDIS (2004) propóe uma evolução estilística e geográfica para a bacia do rio Peruaçu: inicialmente poucos abrigos são pintados, com poucas cores, principalmente preto e vermelho, a temática preferida são as figuras geométricas. Em seguida, nota-se uma diversificação na qual domina o amarelo e o vermelho. Mais tarde, aparece uma outra temática, pequenas figuras desenhadas em cor preta e/ou picoteadas (principalmente antropomorfos e propulsores, estes últimos mais raros na bacia do Peruaçu, mas muito presentes um pouco mais ao norte, no município de Montalvâlnia). Enfim, um último momento apresenta uma explosão de cores, particularmente o branco, acompanhado de um enriquecimento temático (as figuras geométricas são bi ou tricrômicas (Fig. 3).

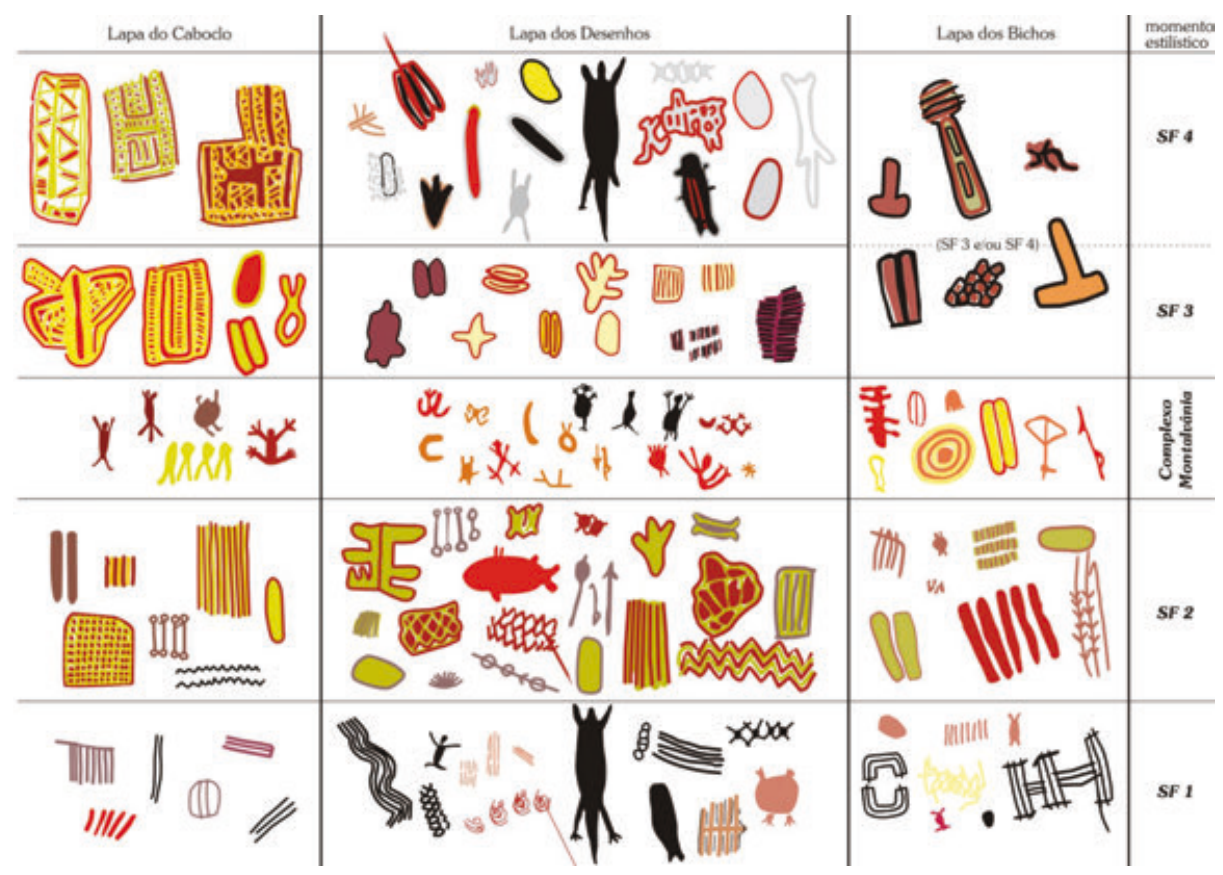

Fig. 3 - Quadro evolutivo de representaçôes rupestres: evolução estilística proposta para abrigos da bacia do rio Peruaçu (de acordo com ISNARDIS, 2004) 
No início da ocupação os grupos utilizavam esses locais como ponto de apoio para, talvez, ir de um setor a outro (sítios de passagem, como apontam os vestígios encontrados); em seguida, a partir de uma apreensão dos espaços ocupados, os abrigos se transformam pouco a pouco em locais à vocação cerimonial, onde são realizados enterramentos, pinturas e oferendas. Se, no Brasil, ao contrário da Europa, náo foram ainda encontrados muitos sinais de ocupação das cavernas, há, no entanto, uma ocupação quase sistemática dos abrigos. Estes, na maior parte das vezes, encontram-se nas margens de entradas de cavernas (pequenas ou grandes). O abrigo é um "acidente" na paisagem, o limite entre a floresta e a caverna, a luz e a escuridão, uma ruptura entre o conhecido e o desconhecido. Talvez seja justamente este o motivo que tenha levado os pré-históricos a estabelecerem os seus sítios cerimoniais nestes locais que para eles poderiam representar a passagem entre dois mundos.

Enfim, a confluência do pequeno rio Peruaçu com o grande São Francisco se realiza no seio de uma grande planície aluvial cárstica, da qual emergem morros calcários residuais. Estes espaços também foram ocupados por grupos humanos desde o início do Holoceno. O grande rio representa uma importante via de penetração utilizada tanto pelos conquistadores, quanto pelos pré-históricos, além de ser uma fonte de alimentos fundamental (um grupo de caçadores precisa de um território enorme para suprir as suas necessidades, salvo se existe no setor um rio piscoso). $\mathrm{Na}$ época da piracema (subida dos peixes para desova) o Surubin (Pseudoplatystoma corruscans), por exemplo, pode apresentar medidas de mais de $1 \mathrm{~m}$ de comprimento e pesar aproximadamente $70 \mathrm{~kg}$. Além disso, as florestas-galeria das margens do rio sustentaram uma fauna específica (por exemplo, grandes macacos), também caçada pelos grupos pré-históricos. Esta grande variedade de recursos alimentares permite uma perenização da implantação humana no compartimento sob forma de grandes aldeias ou acampamentos.

\section{6 - Referências Bibliográficas}

FREITAS, F. \& RODET, M.J (2010) - O que ocorreu nos últimos 2000 anos no vale do rio Peruacu? Uma analise multidiciplinar para abordar os padróes culturais e suas mudanças entre as populaçóes pré históricas daquela regiāo. Revistas do Museu de arqueologia e etnologia, USP. V. 20:109-126.

ISNARDIS, A. (2004) - Lapa, parede, painel. Distribuição geográfica das unidades estilisticas de grafismos rupestres do vale do rio Peruaçu e suas relaçóes diacrônicas. Mémoire de Mestrado, USP : 155 p.

PILÓ, L.B. - 1997. Caracterização regional do carste do vale do rio Peruaçu. O Carste, Belo Horizonte, 9 (2): 22-29.

RODET, M.J. (2006) - Etude technologique des industries lithiques taillées du nord de Minas Gerais, Brésil, depuis le passage Pléistocène/Holocène jusqu'au contact - XVIIIème siècle. Thèse de doctorat de l'Université de Paris- $X$, Nanterre: $516 \mathrm{p}$.

RODET, J. \& RODET, M.J. (1999) - Relatorio de missão no Vale do Rio Peruaçu (Januaria - Itacarambi, Minas Gerais, Brésil), 16-22 dezembro 1.998. Departamento de Arqueologia, Museu de Historia Natural, UFMG, Belo Horizonte, janeiro 1999, 4 p.

RODET, J. \& RODET, M.J. (2001) - Evolution karstique et ressources lithiques archéologiques. L'exemple du Rio Peruaçu (Januária - Itacarambi, Minas Gerais, Brésil). Actes du XIème Congrès National de Spéléologie, Genève (Suisse), 14-16 septembre 2001 : 129-134. 
RODET, J., RODET, M.J., FERREIRA, D., NASCIMENTO, S. \& HUGUET, Y. (2003) - Novos elementos da evolução geomorfológica do vale cárstico do Rio Peruaçu (Januária - Itacarambi, Minas Gerais). Anais do XXVII Congresso Brasileiro de Espeleologia, Januária (MG), 4-14 de julho de 2003, Sociedade Brasileira de Espeleologia, resumo: 2 p.

RODET, M.J., RODET, J. \& HORN, A.H. (2008) - Sistema geomorfológico e sistema antrópico pré-histórico no Brasil. Exemplo do estado de Minas Gerais. $6^{\circ}$ Sinageo - Simpósio Nacional de Geomorfologia, Belo Horizonte, 03-08.08.2008, publicado CD: $10 \mathrm{p}$.

RODET, J., RODET, M.J., MARIANO, D.F., WILLEMS, L. \& POUCLET A. (2005) - New approach of the karstic evolution of the canyon of the Peruaçu river (Januária-Itacarmbi, Minas Gerais, Brazil). $14^{\text {th }}$ UIS Congress, Athens-Kalamos, 23-28 august 2005, CDRom Full Paper : O-33 (6 p.).

RODET, M.J., RODET, J., NASCIMENTO, S.A., MARIANO, D.F., HUGUET, Y. \& SILVA, J.R. (2002) - Metodologia de prospecçóes geoarqueológicas dentro de uma bacia (exemplo da bacia do Rio Peruaçu, Minas Gerais, Brasil). Revista do Museu de Arqueologia e Etnologia da Universidade de São Paulo, 12 : $25-41$.

SPIX, J-B. von \& MARTIUS, C.F-P. von (1981) - Viagem pelo Brasil: 1817-1820. Belo Horizonte, ed. Itatiaia, e São Paulo, Ed. da USP, 2 vol. : 301 p (edição original, 1823-1831). 